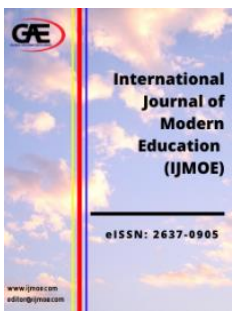

INTERNATIONAL JOURNAL OF MODERN EDUCATION (IJMOE)

www.ijmoe.com

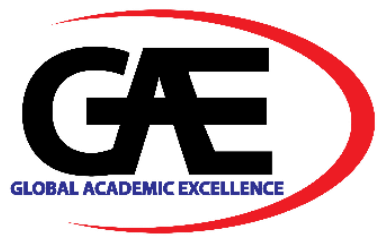

\title{
DEVELOPMENT OF TVET LEADERSHIP MODEL AMONG LEADERS IN TVET INSTITUTIONS
}

Jamelaa Bibi Abdullah" ${ }^{* 1}$, Zainuren Hj Mohd Nor ${ }^{2}$, Akma Haji Abd Hamid ${ }^{3}$, Noor Haslinda Harun ${ }^{4}$, Euis Mariani D. Koswara ${ }^{5}$, Muhamad Azhar Stapa@ Mustapa ${ }^{6}$, Norabeerah Saforrudin ${ }^{7}$, Ahzan Salvina Wati $\mathrm{Ahmad}^{8}$

1 Institute Aminuddin Baki, Genting Highlands Branch, Malaysia.

Email: jamelaa@iab.edu.my

2 Institute Aminuddin Baki, Genting Highlands Branch, Malaysia.

Email: zainuren@iab.edu.my

3 Institute Aminuddin Baki, Genting Highlands Branch, Malaysia.

Email: akma@iab.edu.my

4 Institute Aminuddin Baki, Genting Highlands Branch, Malaysia.

Email: haslinda@iab.edu.my

5 Institute Aminuddin Baki, Genting Highlands Branch, Malaysia.

Email: euis@iab.edu.my

6 Institute Aminuddin Baki, Genting Highlands Branch, Malaysia.

Email: muhamadazhar@iab.edu.my

7 Institute Aminuddin Baki, Genting Highlands Branch, Malaysia.

Email: norabeerah@iab.edu.my

8 Institute Aminuddin Baki, Genting Highlands Branch, Malaysia.

Email: ahzansalvinawati@iab.edu.my

Corresponding Author

\section{Article Info:}

\section{Article history:}

Received date: 25.11 .2021

Revised date: 21.12.2021

Accepted date: 28.12 .2021

Published date: 31.12 .2021

\section{To cite this document:}

Abdullah, J. B., Hj Mohd Nor, Z., Haji Abd Hamid, A., Harun, N. H., Koswara, E. M. D., Stapa@Mustapa, M. A., Saforrudin, N., \& Ahmad, A. S. W. (2021). Development Of TVET
Abstract:

The first and fifth shifts in the Malaysia Education Blueprint 2013 - 2025 is to provide equal access to international quality education and produce highperforming leaders who understand their roles and responsibilities to ensure they can help the Ministry of Education (MOE) provide more competitive students in the job market. The Aminuddin Baki Institute (IAB), is responsible for providing high-impact training to Technical and Vocational Educational Training (TVET) leaders in line with global developments. This study aims to develop a leadership model of TVET among leaders in TVET institutions under the MOE, Malaysia. This study used a design and development research (DDR) approach that emphasizes qualitative and quantitative data collection in three phases, namely the needs analysis phase, the design and development phase, and the evaluation phase. A total of 47 respondents were involved in this study, namely 14 experts (needs analysis phase), 25 experts (design and development), and six experts (evaluation phase). The collected data were 


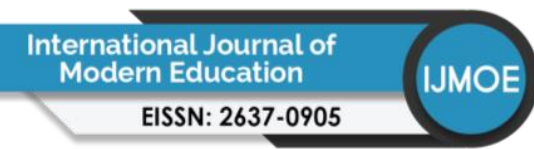

Volume 3 Issue 11 (December 2021) PP. 77-92 DOI: 10.35631/IJMOE.311006

Leadership Model Among Leaders In TVET Institutions. International Journal of Modern Education, 3(11), 77-92.

DOI: $10.35631 / \mathrm{IJMOE} .311006$

This work is licensed under $\underline{\text { CC BY } 4.0}$ analysed using thematic methods (needs analysis phase), the Fuzzy Delphi Method (design and development phase), and the Interpretive Structural Model (evaluation phase). As a result, 13 elements of the TVET leadership model were successfully developed, and their validity evaluated. This model is expected to contribute to the training institutions of TVET leaders and policymakers, as well as TVET-related training modules.

Keywords:

Design and Development Research, TVET, Model, Education, Leadership

\section{Introduction}

The world of education is constantly changing in terms of policy, new knowledge, social trends, politics, economics, technology, and especially the leadership of educational organizations, cited. Technical and Vocational Educational Training (TVET) is an element highlighted by the MOE in an effort to prepare school children for the digital revolution, artificial intelligence, automation and other fast-paced technologies. According to Alias (2019) technical and Vocational Education and education (TVET) is a very important medium for human capital development to make Malaysia a high income and development country by 2020 . Therefore, the MOE has outlined five pillars of the national TVET Leap reform, namely the creation of a TVET coordinating body, the provision of a funding model, the creation of a common ownership model, the provision of TVET (industry) certification and the creation of a unified national TVET brand. In 2020, TVET from pre-school to college will be a very important institution for the economic development of the country.

Therefore, TVET institutions need a leader who is productive, determined and professional and who is able to lead the managed institutions to compete healthily and produce students with world-class knowledge and skills (Mat Nashir et al., 2015). In addition, TVET institutions need to be proactive in responding to the challenges and opportunities, especially in terms of $21 \mathrm{st}$ century leadership, they need to influence change in TVET institutions and systems (UNESCO -UNEVOC International Center for TVET, 2019). At the same time, the IAB has a role in ensuring the continuity of TVET leadership for all schools in Malaysia. The IAB should provide high impact management and leadership training modules as well as leadership consultations in line with the first and fifth shifts in Malaysian Education Development Plan 2013-2025 which is to provide equal access to quality education as well as to produce high performing leaders who understand their roles and responsibilities to ensure that they can support MOE. According to Zainuren (2020), vocational education is the main key to overcoming poverty, strengthening peace, preserving the environment, improving the quality of life and achieving sustainable development.

In this regard, TVET institutions must ensure that the outcomes are of high quality and meet the expectations of National Education Philosophy by producing citizens who are physically, emotionally, spiritually, intellectually and socially balanced, who achieve equilibrium and prosperity of their own and are able to serve the religion, race and nation. TVET education should therefore be in line with the country's educational goals by ensuring that the country's energy needs are met in both the short and long term (Ahmad et al., 2015). This was supported by Mohamad et al. (2009) and Kenayathulla (2021) that TVET is a service provider to individuals, the economy and society and that it has significant relationships with the job 


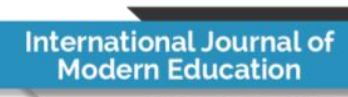

EISSN: 2637-0905

Volume 3 Issue 11 (December 2021) PP. 77-92

DOI: 10.35631/IJMOE.311006

market through the training that students receive at school, college and college levels.

Leaders in TVET institutions must always be sensitive and forward looking, especially when it comes to offering training areas in the institutions. The training areas offered must be dynamic and quality at all levels as well as be able to provide lifelong learning in the development of knowledge communities, skill enhancement training (upskilling) and retraining for the needs of the country's workforce. In addition, TVET institutions also need capable and effective leaders who are able to respond to external and internal organizational environments through: i) Character traits: Consistency, ethics, integrity and control, ii) Networking and building partnerships and alliances, iii) Risk taking, initiatives and innovations in a climate of greater accountability and iv) Attitude: vision, future trends, strategic response to anticipated and proactive needs.

This conceptual framework is illustrated in Figure 1 which shows the development of TVET models among leaders in TVET institutions in Malaysia. As a result of the literature review, there are 23 elements of TVET leadership model, namely mindset, values, problem solving, decision making, building relationships with external parties (industry), mindfulness, effective communication, interpersonal and intrapersonal skills, consultative skills, influencing skills, change leadership, quality assurance, creative, innovative, proactive, ethical leadership, integrity, business (alliance), partnerships, risk taking, initiatives, strategic leaders and entrepreneurship.

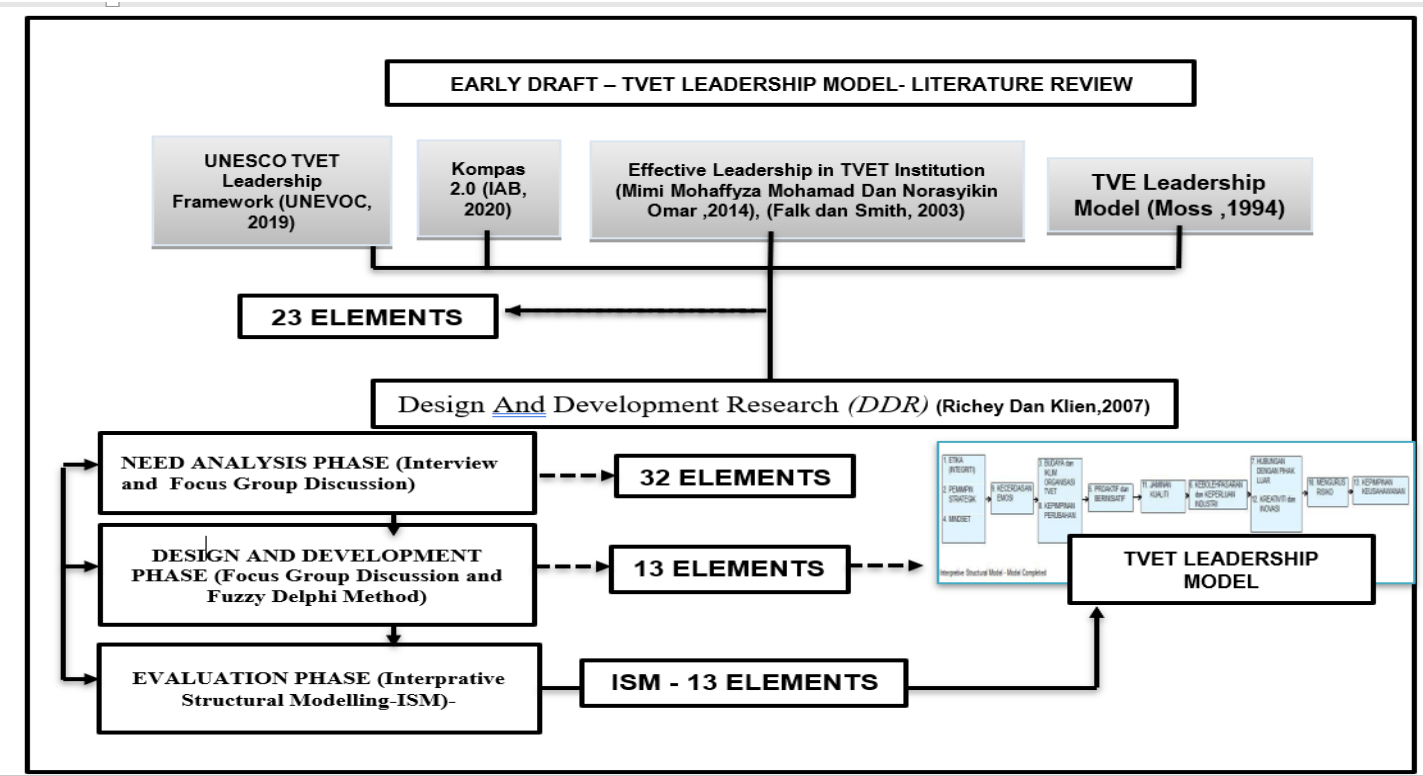

Figure 1: Conceptual Framework Adaptation from Mohd Ridhuan et al. (2016) And Richey and Client (2007)

The purpose of this study is to establish TVET leadership models in TVET institutions in Malaysia using DDR approach in three phases, namely needs assessment phase, design and development phase and evaluation phase according to Malaysian context. The research question for this study:

i. What are the elements of TVET leadership model for TVET institution in Malaysia endorsed by expert agreement? 
Volume 3 Issue 11 (December 2021) PP. 77-92 DOI: 10.35631/IJMOE.311006

The importance of the study lies in the development of TVET Leadership Model. This study is very important to ensure that TVET leaders can effectively manage TVET institutions. The model that emerges from the findings of the study can serve as a guide for Technical and Vocational Education Division (BPLTV) to select the leaders who will manage the TVET institution. It is also a guide for the Institut Aminuddin Baki (IAB) in developing training modules for TVET leaders to meet the training needs of TVET leaders and other leadership programs.

\section{Literature Review}

TVET stands for Technical and Vocational Education and Training. TVET is an education and training process that is job-oriented and primarily based on industry practices. It aims at producing competent manpower in specific fields. The scope of TVET should be based on recognized employment standards with emphasis on practical components, psychomotor skills and industry training. The aim of TVET is to meet industry demand and contribute to economic growth, in line with globalization, the knowledge economy, technological progress and global labour mobility. TVET, which enables an industry-led approach, is essential to provide the skilled human capital needed by industry, especially to support the shift of the economic sector towards knowledge-based activities, in line with the ambition to become a developed nation by 2020 .

In Malaysia, there are six (6) ministries responsible for implementing the TVET agenda: the MOE, the Ministry of Human Resources (KSM), the Ministry of Youth and Sports (KBS), the Ministry of Rural Development (KPLB), the Ministry of Agriculture and Agribusiness (KPIAT) and the Ministry of Construction (KKR). TVET educational institutions are Vocational Colleges (VC), Technical Secondary Schools (SMT), Polytechnics, Community Colleges / ILKA. Public TVET Training Institute were established in 1964 to provide education to youth namely Dusun Tua Youth and National Skills Institute (IKBN) and Kuala Lumpur Industrial Training Institute (ILP). Today there are more than 500 public TVET institutions offering various TVET programs for all levels of education.

Generally, there are two routes to enter the TVET field, namely Sijil Pelajaran Malaysia (SPM) or Form 3 Assessment (PT3). SPM graduates have the option to continue their studies in either the certificate or diploma area in a highly qualified TVET program. In addition, for students who are less academically inclined and for youth outside the education system, there is a special program for National Certificate and Dual Training System (SLDN). The minimum requirements for admission to TVET institutions are based on the offer of the ministry/agency running the program. Graduates of a TVET program are better able to master practical knowledge and skills than graduates of an academic program.

\section{TVET Leadership}

TVET leaders are flexible leaders and there are different leadership styles that should be practiced by a TVET leader, namely digital leadership, leading with integrity, innovative leadership, futuristic leadership, turnaround leadership (improvement), resonant leadership, sustainable leadership, distributed leadership, instructional leadership, TVET leadership, transformational leadership, situational leadership, effective leadership and effective leadership. Leadership styles can be understood using the following definition: According to Sheninger (2014), digital leadership is leadership that focuses on communicating through multiple channels to connect with followers and convey information, and is always responsive 


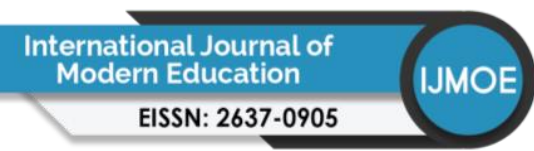

Volume 3 Issue 11 (December 2021) PP. 77-92 DOI: 10.35631/IJMOE.311006

to technological changes over time. Begam (2009) states that a leader of integrity is a leader who possesses the qualities of following the principles of honesty and high morals and possesses perfect authority. Innovative Leadership is defined by Sloane (2007) as a leader who combines different leadership styles to influence employees to develop creative ideas for products and services. Innovative leaders are able to achieve the mission or vision of an organization or group through the use of new technologies and processes. In addition, innovative leaders are able to think innovatively to ensure the continued success and competitiveness of the organization they lead. Moreover, innovative leaders are able to think innovatively to ensure continued success and maintain the competitiveness of the organization they lead. Innovative Leadership is defined by Paul Sloane (2007) as a leader who combines different leadership styles to influence employees to develop creative ideas for products and services. Innovative leaders are able to achieve the mission or vision of an organization or group through the use of new technologies and processes. In addition, innovative leaders are able to think innovatively to ensure the continued success and competitiveness of the organization they lead. Innovative Leadership is defined by Paul Sloane (2007) as a leader who combines different leadership styles to influence employees and develop creative ideas for products and services. Innovative leaders are able to achieve the mission or vision of an organization or group through the use of new technologies and processes. In addition, innovative leaders are able to think innovatively to ensure the continued success and competitiveness of the organization they lead.

Frank Feather (2006) sees futuristic leadership as the ability of a leader to visualize and think further into the future about new ideas about customers, products, services, strategies, and business models, and to implement contemporary ideas to remain competitive in a world that is constantly changing rapidly. Resonant leadership according to Goleman (2005) is a leader who has an effective team and organization, is positive and energetic, and is able to continually reorganize systems and processes so that nothing is left behind in strengthening the organization.

Hargreaves and Fink (2003) explain that sustainable leadership is a leader who is able to work with his followers to develop an organization without compromising the development and environment in the present and future. According to Alma Harris (2002), Distributed Leadership is the ability of a leader to distribute tasks to subordinates based on the expertise, skills and knowledge of subordinates in an organization. Leadership skills are the ability to self-express, teamwork, and organization (National Association from Secondary School Principals (NASSP), 2001). Moss (1994) described 37 TVET leadership attributes as leaders who lack certain characteristics.

Taylan (2020), described transformational leadership as a leadership style in which leaders mobilize followers to identify needed change, create a vision to guide change through inspiration, and implement change in partnership with committed members of the group. Demissie (2017) describes situational leadership as a leader who is able to vary his leadership style according to the capabilities and determination of his followers in the organization.

TVET leadership as formulated by Falk and Smith (2003) consists of identifying key qualities of the interactive processes involved in leadership, qualities that promote positive learning of knowledge and identity and in turn contribute to improved networks, relationships and collective action. The characteristics are as follows: 


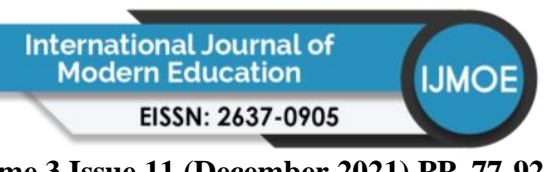

Volume 3 Issue 11 (December 2021) PP. 77-92 DOI: 10.35631/IJMOE.311006

i. Building internal networks: is relevant knowledge of skills, information and values congruently available for existing purposes?

ii. Building relationships between internal and external networks: How healthy are the links built and maintained between internal and external networks in a community?

iii. story development: How effective is the building and shared experience (including norms and attitudes) and understanding of personal, family, community and broader societal history?

iv. Developing a shared vision: how systematic and inclusive are the sources of knowledge and identity (including norms, values and attitudes) in reconciling past shared experiences with desired future scenarios?

v. Building shared communication: how clear and systematic are communicative practices in terms of physical locations, rules and procedures?

vi. Developing a changed sense of self and shared identity: How explicit and systematic are the occasions in which these interactions take place?

\section{Methodology}

This study uses DDR with three main phases, namely the needs analysis phase, the design and development phase, and the evaluation phase (Richey \&Client, 2007). In this study, the type is II, which allows only two or one phase, but to show the perfection of DDR, the needs analysis phase was also included (Traceys, 2002). In data collection, survey method was used in this study and the combined approach of sequential exploration (exploratory sequential mixed methods approach) was preferred, i.e., qualitative approach was started followed by quantitative approach. A total of 42 people who were directly involved in the implementation process of this study were interviewed. These were policy makers in the field of vocational education and training, people responsible at the management level of the CPM vocational education and training institutions, MTUN higher education institutions and private institutions directly and indirectly involved in the CPM vocational education and training institutions.

In the analysis phase of the required data collection techniques, interviews and focus group discussions (FGD) are conducted to find out the extent to which the TVET implementation proposals are consistent with the views of the researchers in the literature surveys. This is in line with the views of Limbrey et al., (2012) who state that the primary performance of leadership in the organization must first be identified before it is established. This is to avoid the emergence of a model that is difficult for leaders in VET institutions in Malaysia. Therefore, the needs analysis will be conducted in the form of exploration to identify the most important implementation of leadership in VET institutions in Malaysia based on the criteria established through interviews and observations.

Design and phase and phase and development phase. The results of the data collection and development phase were collected by FGD and analyzed using Fuzzy Delphi Techniques (FDM) to confirm the results of developing the design of TVET leadership model. The evaluation phase using the Interprative Structural Model (ISM) is the final phase in which the validity of the model is verified. After going through the three phases of the process, a TVET leadership model was created.

\section{Findings}

Research using DDR has successfully produced a TVET leadership model. The initial findings of the model are the result of brainstorming from the review has acquired several TVET 
Volume 3 Issue 11 (December 2021) PP. 77-92 DOI: 10.35631/IJMOE.311006

leadership concepts based on the UNESCO leadership framework (UNEVOC, 2019), KOMPAS 2.0 (2020), effective leadership in TVET institutions (Mohamad and Omar, 2014), Vocational Technical Education (TVET) Leadership Model (Jerome Moss) , 1995) and Falk and Smiths (2003) effective leadership model. The results of the study show findings for each phase starting from literature review (23 items), needs analysis phase (32 items), design and development phase (13 items) and evaluation phase (13 items). Table 1 below shows an overall summary of the findings of the elements of the TVET leadership model for each phase.

Table 1: Summary of Overall Findings of the TVET Leadership Model

\begin{tabular}{|c|c|c|c|}
\hline Literature review & $\begin{array}{c}\begin{array}{c}\text { Needs analysis } \\
\text { phase }\end{array} \\
\end{array}$ & $\begin{array}{c}\text { Design and development } \\
\text { phase } \\
\end{array}$ & Assessment phase \\
\hline 1. Mindset, & 1. Building & 1. Ethics and integrity & 1. Ethics/Integrity \\
\hline 2. Value & Relationships & 2. Strategic Leader & 2. Strategic \\
\hline 3. Problem solving & With External & thinking skills deep, & Leader \\
\hline $\begin{array}{l}\text { 4. Making } \\
\text { decisions }\end{array}$ & $\begin{array}{l}\text { Parties } \\
\text { (Industry) }\end{array}$ & $\begin{array}{l}\text { long and big thinking } \\
\text { predictive }\end{array}$ & $\begin{array}{l}\text { 3. Mindset } \\
\text { 4. Emotional }\end{array}$ \\
\hline 5. Building & 2. Change & 3. Culture and Climate & Intelligence \\
\hline Relationships & Leadership & of TVET & 5. Culture and \\
\hline With External & 3. Strategic & organizations & Climate of \\
\hline Parties & Leader/ deep, & presource management & TVET \\
\hline (Industry) & long and big & TVET technology & Organization \\
\hline 6. Mindfullness & thinking & management, & 6. Leadership for \\
\hline 7. Effective & 4. Resource & teamwork TVET & Change \\
\hline $\begin{array}{l}\text { communication, } \\
\text { 8. Interpersonal }\end{array}$ & $\begin{array}{l}\text { management } \\
\text { 5. Teamwork }\end{array}$ & $\begin{array}{l}\text { organizational } \\
\text { management }\end{array}$ & $\begin{array}{l}\text { 7. Proactive and } \\
\text { Initiative }\end{array}$ \\
\hline and & 6. Problem & 4. Mindset & 8. Quality \\
\hline Intrapersonal & solving & 5. Proactive and & guarantee \\
\hline Skills & 7. Making & proactive & 9. Marketability \\
\hline 9. Negotiation & decisions & 6. Marketability and & and Industry \\
\hline Skills & 8. Quality & Industry Needs & Needs \\
\hline 10. Influencing & Assurance & supply and demand & 10. Relations with \\
\hline Skills & 9. Emotional & 7. Building & External \\
\hline 11. Change & intelligence & Relationships With & Parties \\
\hline Leadership & 10. Technology & External Parties & 11. Creative and \\
\hline 12. Quality & management & agreement,consultation & innovative \\
\hline Assurance & 11. Mindset & partnership & 12. Managing Risk \\
\hline 13. Creative & 12. Interpersonal & 8. Change Leadership & 13. Entrepreneurial \\
\hline 14. Innovative & and & problem solving, & Leadership \\
\hline 15. Proactive & Intrapersonal & making decisions & \\
\hline 16. Ethical & Skills & 9. Emotional & \\
\hline Leadership & 13. Negotiation & intelligence & \\
\hline 17. Integrity & Skills & emotional control & \\
\hline 18. Allience & 14. Creative & moral imperative & \\
\hline 19. Partnership & 15. Innovative & mindfullness & \\
\hline 20. Risk takers & 16. Proactive & effective communication & \\
\hline $\begin{array}{l}\text { 21. Take the } \\
\text { initiative }\end{array}$ & $\begin{array}{l}\text { 17. Allience } \\
\text { (agreement) }\end{array}$ & $\begin{array}{l}\text { interpersonal and } \\
\quad \text { intrapersonal skills }\end{array}$ & \\
\hline 22. Strategic Leader & 18. Partnership & 10. Managing Risk & \\
\hline
\end{tabular}




\begin{tabular}{|c|c|c|}
\hline 3. Entrepreneurship & $\begin{array}{l}\text { 19. Managing Risk } \\
\text { 20. Take the } \\
\text { initiative } \\
\text { 21. Predictive } \\
\text { 22. Emotional } \\
\text { control } \\
\text { 23. Thinking skills } \\
\text { (deep, big, } \\
\text { long) } \\
\text { 24. Entrepreneurial } \\
\text { Leadership } \\
\text { 25. Imperative } \\
\text { morality } \\
\text { 26. Mindfullness } \\
\text { 27. Etiquette } \\
\text { 28. Integrity } \\
\text { 29. Industry Needs } \\
\text { 30. Marketability } \\
\text { 31. Supply and } \\
\text { demand } \\
\text { 32. TVET } \\
\text { organizational } \\
\text { management }\end{array}$ & $\begin{array}{l}\text { 11. Quality guarantee } \\
\text { 12. Creative and } \\
\text { innovative } \\
\text { 13. Entrepreneurial } \\
\text { Leadership }\end{array}$ \\
\hline
\end{tabular}

\section{Discussion and Conclusion}

The results clearly show that the 13 final elements identified in the evaluation of the model are considered by the experts as the most important elements needed by the leaders of TVET institutions at MOE, such as in Vocational Colleges, Technic Schools and Daily Secondary Schools, which offer Upper Secondary Vocational Education Program (PVMA) and Upper Secondary Industrial Apprenticeship Program (PIMA). Figure 2 shows that the element of quality assurance is in the middle range and all experts agree that quality assurance is a balanced factor for internal and external factors. The elements of ethics/integrity, strategic leadership, mindset, emotional intelligence, organizational culture and climate in professional education, leadership in change, and proactive/initiative are factors that influence external factors such as marketability/industry needs, external relations (networking), creativity and innovation, risk management, and entrepreneurial leadership. 


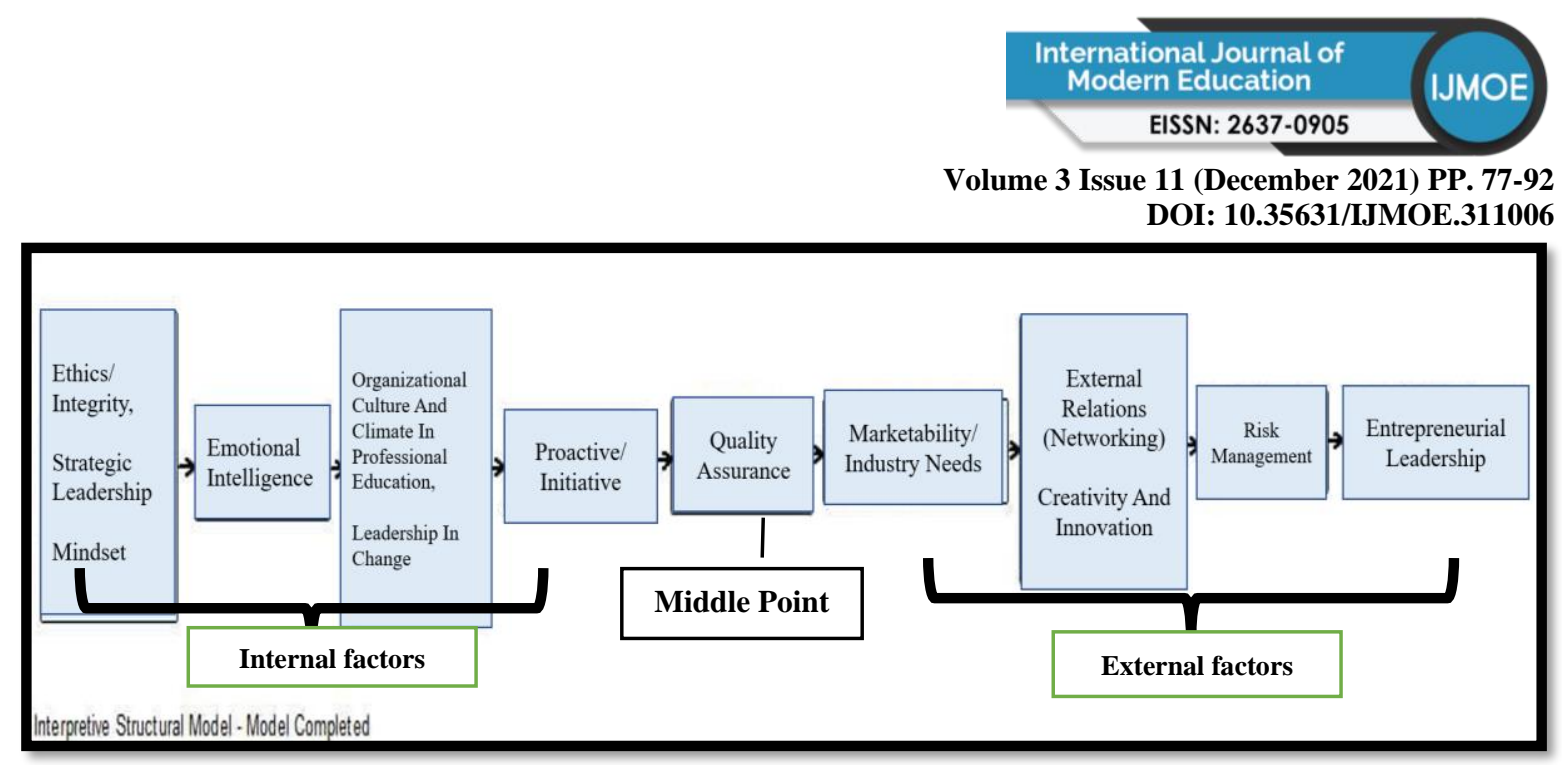

Figure 2: Relationship of TVET Leadership Elements, MOE

\section{Internal Factors}

Elements of ethics and integrity are paramount for a TVET leader, i.e., they must have internal consistency in terms of their own quality, i.e., trust, honesty and the ability to perform their duties based on positive values practiced in the performance of their duties in the management and administration of TVET institutions. This is consistent with adherence to policies established by MOE for TVET institutions such as selection of students based on qualifications, efficient management of assets and finances, performance of duties in accordance with SOPs (acceptance of contributions), constant prioritization of organizational interests (no personal interests), course offerings in institutions, and marketability to meet established goals. Compliance must be consistent and uncompromising, always emphasizing strong moral and ethical principles and values in the practice of TVET facilities. In addition, the leaders of VET institutions must indicate the moral and ethical behaviors that must be followed by outlining some basic principles or measures to determine right and wrong behavior that can be accounted for. This shows that the elements of integrity and ethics are interlinked and essential for a leader in a TVET institution under the human development agenda (UNESCO -UNEVOC) as TVET leaders are responsible for change at institutional, national and regional levels (UNESCO UNEVOC, 2019). In addition, this finding is consistent with the findings of Falk and Smith (2003) that the elements that are critical to the attributes and character of TVET leaders include consistency, ethics, integrity and control.

In addition to ethics and integrity, strategic thinking is also considered a priority for a TVET leader, i.e., the ability to identify and predict the needs of the organization in the future. In the context of strategic thinking, thinking skills are the ability of a leader in a TVET school/college/ PIMA the ability to draw the shape of a desired future goal beyond current experience and a 5year time frame to influence the citizens of the organization to understand the importance of management to the future of TVET. TVET leaders are able to think broadly (Big), i.e., recognize how to connect and interact with other organizations and the external environment, think deeply (Deep Thinking), i.e. the ability to explore their own thinking in depth by considering the interpretation of past experiences or expectations in the future that can be adopted in the future, and think broadly (Long) by being able to anticipate the future and understand organizational alternatives in the time front. This is also in line with the view of Feather (2006) that leaders in professional education must have a future-oriented leadership. The next element is the mindset of TVET leaders, i.e., applying a deep mindset regarding the roles and responsibilities as a TVET leader leads to confidence in leadership. In addition, TVET leaders demonstrate a shift in thinking that translates into action and results in their 


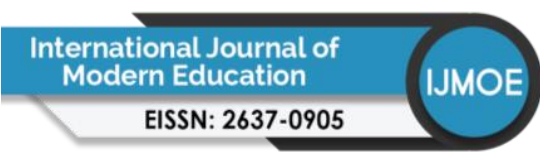

Volume 3 Issue 11 (December 2021) PP. 77-92

DOI: 10.35631/IJMOE.311006

ability to work together to achieve the vision and mission of the organization. This mindset is important for TVET leaders because if they are leading a TVET institution, they should understand the VET system, know the spirit and soul of TVET and in turn understand and know the direction of VET. This is underscored by the study of Ahmad (2015) which states that TVET leaders must be prepared to make a paradigm shift to higher levels of leadership in TVET institutions.

Emotional intelligence is the second group after ethics, strategic leaders, and mindset and is required to develop the ability to control and manage one's own emotions as well as the emotions of others. According to Goleman (2005), a leader must possess the inner strength to move in a positive direction, strive for self-reflection, be disciplined, calm, empathetic, and able to move a person/team in a mutually agreed upon direction to achieve organizational excellence. Emotional prefixes are part of the element that should be prioritized as the first choice for expert agreement, i.e., the ability to control emotions when performing tasks that often involve people and being able to mentor and also be a role model in dealing with problems related to emotions or the environment that influences those emotions. TVET leaders must also be able to recognize, face and communicate or interact with others, either individually or through the ability to communicate with themselves to think, analyze and reason in order to effectively control themselves in thought and action. This in turn leads to a persuasive moral stance - with the principle of inner awareness (mindfulness/voice of the heart) able to act as a leader of the organization and know their own best interests. They also have the ability to bring people in the organization together to achieve the stated vision and mission.

Only when the key fundamentals such as ethics, strategic thinking, mindset and stable emotions are in place, a TVET leader can create an excellent organizational culture and climate by prioritizing the efficient and effective management of TVET organizations, effective management of resources including managing the latest technology and teamwork. In this regard, VET leaders must shape the culture and climate of the organization and manage resources in line with organizational goals by managing the technology base to achieve a competitive advantage. They must prepare students for the era of IR 4.0 and online learning and be sensitive to current technological developments. They also need to be able to get internal and external citizens of the organization to work together to achieve the goals. According to Ambotang and Sulaiman (2018), TVET leaders must have experience in leading TVET organizations by providing space and opportunities that "support the learning of lecturers or teachers, be a learning model, encourage innovation, give appreciation and full recognition, and continuously develop the potential of school members by providing motivation and inspiration, and building intellectual stimulation. In addition, TVET leaders must have experience in planning and delivering appropriate training to their subordinates to produce not only graduates/students who have skills in technical and professional areas, but also marketability (graduate employability).

In addition, they are able to manage resources in line with the objectives of the strategic organization, taking into account both equity and continuous development aspects through monitoring and evaluation when setting objectives. TVET leaders must be knowledgeable about technology management (Technology Management), which is a set of management disciplines that enable organizations to manage their technology base to achieve a competitive advantage. Technology Management X in TVET leaders also refers to the effort to understand and recognize the different types of technology management that exist in different sectors and 
Volume 3 Issue 11 (December 2021) PP. 77-92 DOI: 10.35631/IJMOE.311006

can be associated with learning and relearning needs. TVET leaders must also be able to mobilize internal and external members of the organization to work together in a collaborative manner that focuses on achieving set goals by considering the strengths of individuals in accordance with set policies.

The elements of change leadership are consistent with the culture and climate of the TVET organization, which are in line with the recommendations of the leadership model UNESCO UNEVOC (2019), i.e., effective TVET leaders have the vision, knowledge and skills to drive change as they are able to make strategic decisions to facilitate the transformation of TVET and contribute to the promotion of a more inclusive, equitable and sustainable world for all. Accordingly, TVET leaders are in a position to drive change. They are able to solve problems and make decisions to ensure the sustainability of the changes made in the organization.

The next element is the ability of TVET leaders to be proactive and mobilize the TVET institutions. TVET leaders can act on their own initiative without waiting for instructions from superiors. A leader must be prudent in decision making, i.e. take the right action at the right time (Torlak et al., 2021). In addition, TVET leaders are able to take opportunities and ideas and expand them to gain new opportunities. They have the power to complete a task without waiting for others to intervene or give instructions. They are also constantly on the lookout for new ideas to improve work outcomes beyond what is expected.

\section{Middle Point}

The next element is quality assurance which is the middle point and the element that balances the internal and external factors. Quality assurance (QA) is a means of preventing defects and deficiencies in the manufacture of products and preventing problems in the delivery of products or services to customers; it is defined by ISO 9000 as "a quality management department directed toward providing confidence that quality requirements will be met" (ISO -9000, 2005). Accordingly, TVET leaders must have the knowledge to ensure that systematic processes are implemented to maintain the desired level of quality of a service or product, especially by observing each stage of the delivery or production process, which provides confidence that quality requirements will be met.

\section{External Factors}

The next element is marketability and industry demand, that is, the skills and experience of managers in identifying labour market demand or marketability for TVET graduates and matching them with course offerings in TVET institutions, and ensuring that TVET graduates are trained with soft skills or "employability" skills based on economic focus areas for each graduate's marketability, namely 70 percent in the skilled sector, 20 percent advanced studies and 10 percent techno-entrepreneurship. According to Abelha et al. (2020) the quality of trainees in training centers should be characterized by employability and marketability skills based on the extent to which trainees are integrated into the labour market. Accordingly, TVET institutions need to produce highly skilled graduates with a better future to meet the needs of the industry. Moreover, experienced heads of TVET institutions can plan and implement proper training so that their subordinates not only produce graduates or students who have skills in technical and vocational fields but also marketable. In addition, a TVET leader must also have experience of industry needs as this will help prepare graduates based on economic focus areas according to the identified region or locality i.e., graduates have personality, demeanour, confidence, communication skills and ability to make quick decisions, technical skills. and 


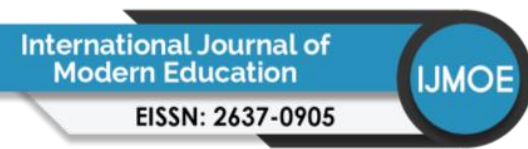

Volume 3 Issue 11 (December 2021) PP. 77-92 DOI: 10.35631/IJMOE.311006

academic knowledge so that the TVET graduates produced are balanced, holistic, entrepreneurial and transform into highly skilled workers who contribute to the productivity and economic growth of the country. This is enshrined in the Vision Statement for Shared Prosperity (WKB) 2030 (Ministry of Economic Affairs, 2021).

The element that is an external factor is the relationship with external parties, namely the ability to collaborate with industry and the community, as well as negotiate skilfully to build smart partnerships and create agreements to establish good relationships with external parties to enhance the potential skills of students and members of the organization. In building relationships with external parties, elements in TVET leaders such as effective communication and interpersonal and intrapersonal skills are the most important factors that contribute to the success of a negotiation to reach a joint decision with the customer because it can help identify the needs and desires of customers who can ultimately produce products. that meet the wants and needs of the group (Okoro et al., 2017). The selection of relationship partners is not unplanned but systematic. TVET leaders are able to conduct negotiations such as influencing, persuading, problem solving, conflict resolution and decision making along with people consulted by the industry or community and other stakeholders. This is to ensure that strategic collaboration with the private sector and the public remains possible. In addition, TVET leaders also seek to establish mutually beneficial arrangements, particularly between countries or organizations, to achieve shared strategic goals, reduce risks while increasing benefits, and/or leverage resources.

These findings are consistent with Grayson and Baldwin's (2007) model, i.e., TVET leaders can negotiate, i.e., influence, persuade, solve problems, resolve conflicts and make decisions jointly with people consulted by industry or community and other stakeholders. This is to ensure that strategic collaboration with the private sector and the public remains possible. In addition, VET leaders seek to establish mutually beneficial arrangements, particularly between countries or organizations, to achieve shared strategic goals, reduce risks while increasing benefits, and/or leverage resources. These findings are consistent with Grayson and Baldwin's (2007) model, i.e., TVET leaders can engage in negotiations such as influencing, persuading, problem solving, conflict resolution and decision making together with individuals consulted by industry or community and other stakeholders. This is to ensure that strategic collaboration with the private sector and the public remains possible. In addition, TVET leaders also seek to establish mutually beneficial arrangements, particularly between countries or organizations, to achieve shared strategic objectives, reduce risks while increasing benefits and/or leveraging resources.

These outcomes are consistent with Grayson and Baldwin's (2007) model, i.e., resolving conflicts and making decisions jointly with individuals consulted by industry or community and other stakeholders. This is to ensure that strategic collaboration with the private sector and the public remains possible. In addition, TVET leaders also seek mutual benefit arrangements, particularly between countries or organizations with the aim of achieving common strategic goals, reducing risks while increasing benefits, and/or leveraging resources. These findings are consistent with Grayson and Baldwin's (2007) model, i.e., particularly between countries or organizations with the aim of achieving common strategic goals, reducing risk while increasing rewards and/or leveraging resources. These results are consistent with Grayson and Baldwin's (2007) model, i.e., particularly between countries or organizations with the goal of achieving common strategic goals, reducing risk while increasing rewards and/or leveraging resources. 


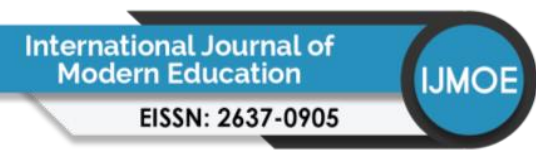

Volume 3 Issue 11 (December 2021) PP. 77-92

DOI: 10.35631/IJMOE.311006

These findings are consistent with Grayson and Baldwin's (2007) model, i.e., the priority that administrators must have been to have a network, collaborate, and build (connect, collaborate, and create) good and ongoing relationships with the industry. Every manager must be good at managing organizational relationships with stakeholders, especially in the organizational environment. Abbas et al (2012) argued that administrators need to be good at adapting to any situation and building many relationship networks with other organizations to facilitate organizational affairs.

Creative and innovative elements in line with the innovative leadership proposal, that is, the ability of TVET leaders to think innovatively, be creative, remain committed and persistently improve processes, products and services. TVET leaders to think creatively, make decisions and do things in different ways and influence the citizens of institutions to accept change in line with current developments in TVET. TVET leaders also need to come up with many new ideas and inspire, motivate and collaborate with organizational staff to continue to innovate for institutional excellence.

The element of risk management is among the most important and is addressed in several leadership models such as the TVET leadership model (Moss, 1994) and Falk and Smith (2003). TVET leaders are able to manage risk responsibly to absorb any contingencies that may arise in the organization and are prepared to solve problems that arise in the organization they lead. In ideal risk management, a prioritization process follows in which the risks with the greatest losses (or impacts) and the greatest likelihood of occurrence are dealt with first, and the risks with the least likelihood of occurrence and fewer losses are dealt with in descending order. In practice, the process of determining overall risk is difficult, and balancing the resources used to mitigate risk between risk and probability of occurrence can be difficult, and balancing the resources used to mitigate risk between risk with high probability of occurrence and high probability of loss but low probability of occurrence is often misunderstood. In the context of this study, risk management is the ability of a leader in a vocational college/technic school/ PIMA is responsible for perceiving all the possibilities that will occur in the organization and ready to solve problems that arise.

The element of entrepreneurial leadership is an important factor and should be present in all TVET leaders because they are a pillar in implementing guidance to the citizens in the organization, especially the students. TVET leaders must provide a platform or opportunity for students to get trained, register a business, raise capital as well as explore suitable spaces to start a business. Students need to be provided with skills and given a career opportunity so that they can become entrepreneurs in line with TVET transformation. The Strategic Action Plan for the Transformation of Technical and Vocational Education also emphasizes on producing $10 \%$ entrepreneurs in various fields. Vocational refers to any individual ability, either in the form of technical skills, either in the form of hard skills or soft skills and natural talents. Individuals with high entrepreneurial vocation will think about how to turn their vocation into entrepreneurship but find employers who want to use their vocation in the form of work and paid salaries or wages. TVET leaders need to be aware of the importance of the concept of entrepreneurship and promote a culture of entrepreneurship among members of the organization to develop risk-taking, creativity and innovation in business and employment and to stimulate entrepreneurial interest. 


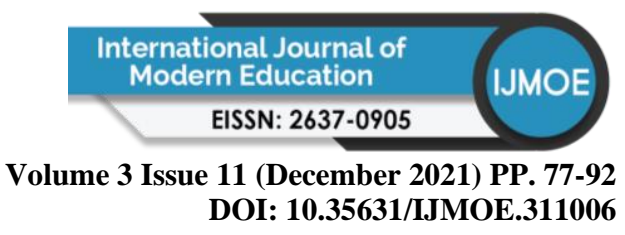

This study has successfully created a model for TVET Leadership Model in the Malaysian context that can be used as a guide for leaders in TVET institutions, MOE. In this regard, there are several implications and suggestions:

i. Develop a TVET leadership module based on the 13 elements of the TVET leadership model developed for training all managers, middle managers in Vocational Collage, Technique Schools, Secondary Daily Schools offered PIMA /PVMA.

ii. To form a group of experts among IAB faculty who will conduct TVET leadership training.

iii. Produce a TVET leadership handbook to be shared with BPLTV.

iv. Conduct further research with universities to develop TVET leadership models among leaders in Malaysian tertiary institutions.

v. Conduct a comparative regional study with TVET operating countries such as Indonesia, Thailand, Brunei, Vietnam, and Singapore.

\section{References}

Abbas, G., Iqbal, J., Waheed, A., \& Riaz, M. N. (2012). Relationship between Transformational Leadership Style and Innovative Work Behavior in Educational Institutions. Journal of Behavioural Sciences, 22, 19 - 32.

Abelha, Marta; Fernandes, Sandra; Mesquita, Diana; Seabra, Filipa and Ferreira, Ana Teresa Oliveira. (2020). Graduate Employability and Competence Development in Higher Education-A Systematic Literature Review Using PRISMA. Sustainability 2020, 12, 5900; doi:10.3390/su12155900

Ahmad, Hadijah. (2015). Leadership in TVET for the 21st Century: Challenges, Roles and Characteristics. Procedia - Social and Behavioral Sciences 195:14711476DOI: 10.1016/j.sbspro.2015.06.446

Ahmad, M.J, Jalani, N.H, Hasmori, A.A (2015) TEVT di Malaysia: Cabaran dan Harapan. Seminar Kebangsaan Majlis Dekan-Dekan Pendidikan Awam 2015

Alias, Maizam (2019). TVET Research as an Enabler of Human Capital Development: Sharing of Experience from Malaysia. ICIEVE 2019 Bandung Indonesia 26 November 2019

Ambotang, A.S and Sulaiman, G (2018), Sumbangan kebolehkerjaan pelajar terhadap modal insan produktif. UMSeprint195222018-03-26T01:43:55Z http://eprints.ums.edu.my/19522/

Begam, Mumtaz (2009) Learning Organisation- Membentuk Budaya Belajar dalam Organisasi, PTS Professional, 2009

Demissie, M.M (2017) Evaluating The Perceived Effectiveness Of The Leadership Styles Of Deans In Ethiopian Governmental. Dissertation for Doctor Of Education In The Subject Educational Management At The University Of South Africa Technical And Vocational Education And Training (TVET) College

Economic Planning Unit. (2010). 10 ${ }^{\text {th }}$ Malaysian Planning. Department of Prime Minister. Putrajaya.

Falk, Ian dan Smith, Tony. (2003). Leadership In Vocational Education And Training Leadership By Design, Not By Default. Australian National Training Authority, 2003. Kensington Park, Australia

Feather, Frank (2006) Futuristic Leadership A-Z Paperback - May 2, 2006

Goleman.D (2005). Emotional Intelligence: Why It Can Matter More Than IQ. Random House USA Inc. New York, United States

Grayson Dan Baldwin (2007) Grayson, C., \& Baldwin, D. (2007). Leadership networking. Greensboro, NC: Center for Creative Leadership. 
Volume 3 Issue 11 (December 2021) PP. 77-92 DOI: 10.35631/IJMOE.311006

Hargreaves, A., \& Fink, D. (2003). The Seven Principles of Sustainable Leadership by. Educational Leadership, 61(December), 8. Retrieved from http://www.marylandpublicschools.org/NR/rdonlyres/F7D49A8D-E9D0-4C499DE6-3A878BC9F1F4/18748/seven_principles.pdf

Kenayathulla, H.B (2021). Are Malaysian TVET graduates ready for the future? Higher Education Quarterly DOI: 10.1111/hequ.12310

Limbrey, Meikle dan Berggren (2012), Limbrey, P., Meikle, A., \& Berggren, E. Leaders drive productivity: Are you buiding a high-performance environment? Success Factors

Mat Nashir, Irdayanti. Mustapha, Ramlee. \& Yusoff, Abdullah (2015). Membangunkan Instrumen Kepimpinan Dalam Sistem Pendidikan Teknik Dan Vokasional: Penggunaan Teknik Delphi Terubah Suai. Journal Of Quality Measurement And Analysis. JQMA 11(1) 2015, 41-47

Ministry of Education. (2013). Malaysian Education Development Plan 2013-2025 Putrajaya. Ministry of Education. (2019). (https://www.moe.gov.my/pendidikan/tvet/sekolah-menengahteknik/aliran-teknikal-di-sekolah-menengah-teknik-ambilan-januari-2019).

Mohamad, M. M., Razali, C., \& Abd Jalil. (2009). The need of lifelong learning for instructors in vocational training institutions. International Conference on Teaching and Learning in Higher Education 2009

Mohamad, Mimi Mohaffyza and Omar, Norasyikin (2014). Effective Leadership Tactics: Vision to Raise (TVET) Institutions Level. Developing Country Studies ISSN 2224607X (Paper) ISSN 2225-0565 (Online). Vol.4, No.16, 2014 (Ms. 27)

Mohd Ridhuan, M.J, Saedah, S., Farazila, Y., Nurulrabihah, M.N., Zaharah, H., \& Ahmad Arifin, S. (2016). Aplikasi Teknik Fuzzy Delphi Terhadap Keperluan Elemen Keusahawanan Bagi Pensyarah Kejuruteraan Politeknik Malaysia. International Journal of Business and Technopreneurship, 5(1), 135-150.

Moss, Jerome. (1994). Gender, Leadership, and Vocational Education. JITE v33n1. Volume 33, Number 1, Fall 1995

National Association from Secondary School Principals (NASSP), 2001). 21st Century School Administration Skills. Association Drive, Reston, Virginia.

Okoro. E, CWashington. M, and Thomas. O. (2017). The Impact of Interpersonal Communication Skills on Organizational Effectiveness and Social Self-Efficacy: A Synthesis, International Journal of Language and Linguistics Vol. 4, No. 3, September 2017

Richey, R.C., \& Klein, J. D. (2007). Design and Development Research. New York: Routledge.

Richey, R., \& Klien, J. (2007). Design and development research: Method, strategies and issues. London: Erlbaum.

Sheninger, Eric C. (2014). Digital Leadership: Changing Paradigms for Changing Times (1st ed.). United States of Americ: Chapman \& Hall/CRC: Sage Publications.

Sloane, Paul. (2007). The Innovative Leader: How to Inspire Your Team and Drive Creativity. Kogan Page Publishers.

Taylan, Budur (2020) Effectiveness of Transformational Leadership among Different Cultures. International Journal of Social Sciences \& Educational Studies, 7 (3). pp. 119129. ISSN 24091294

Torlak, Nuri Gökhan. Demir, Ahmet. Budur, Taylan. (2021).Decision-making, leadership and performance links in private education institutes. Rajagiri Management Journal. ISSN: 0972-9968 
Volume 3 Issue 11 (December 2021) PP. 77-92 DOI: 10.35631/IJMOE.311006

UNESCO-UNEVOC. (2019). UNEVOC TVET Leadership Programme 2019. Capacity building for transformational TVET leaders: Vision, knowledge and skills. UNESCOUNEVOC International Centre for TVET. German

Zainuren Mohd Nor (2020). Transformasi Pendidikan Vokasional. Penerbitan PNB. Kuala Lumpur. 